\title{
KEBAKARAN HUTAN DAN LAHAN DI PULAU RUPAT, RIAU
}

\author{
Forest and Land Fires on Rupat Island, Riau
}

Bambang Hero Saharjo ${ }^{* *}$ dan Mar'ie Al Fauzan²

(Diterima Desember 2020/Disetujui Februari 2021)

\begin{abstract}
Forest and land fires in Riau province generally occur on peatlands. This is due to the large area of peatlands and intensive land conversion. Peat fires result in high PM 2.5 pollutant content, as happened on Rupat Island, Meranti Islands. Rupat Island has a history of repeated cases of forest and land fires in 2015 and 2019. This study aims to analyze the background of the causes of forest and land fires on Rupat Island, Riau Province. The research was carried out through several stages, namely data collection, data processing and data analysis. Forest fires on Rupat Island caused PM 2.5 content in February and March to have values above the PM 2.5 content threshold. Based on the results of the study, it is known that the background causes of forest and land fires on Rupat Island, Riau, are caused by poor canal management, damaged peat conditions and the influence of the arrival of El Nino. This is the cause of the widespread forest and land fires on Rupat Island.
\end{abstract}

Keywords: forest fires, peat land, Rupat island

\section{PENDAHULUAN}

Kebakaran hutan di Indonesia selalu terjadi setiap tahunnya yang disebabkan oleh faktor alam dan perbuatan manusia. Kebakaran hutan yang disebabkan oleh faktor alam memiliki kemungkinan yang kecil. Sumber api dari alam berupa petir dan aliran lahar memiliki kontribusi kecil dari semua kasus kebakaran hutan dan lahan di Indonesia. Hanya 1\% diantaranya yang terjadi secara alamiah (Syaufina 2008).

Kegiatan perubahan lahan hutan dengan pembakaran yang dilakukan manusia ditunjukkan untuk menyiapkan lahan, baik yang dilakukan oleh masyarakat maupun oleh pengelola Kawasan Hutan Tanaman Industri (HTI) atau perkebunan. Tanah mineral dan gambut dengan dampak kebakaran terbesar ada di lahan gambut. Kebakaran di lahan gambut memiliki kerugian ekologis akibat hilangnya lapisan serasah serta polusi yang besar sehingga potensi asap lebih tinggi. Asap hasil kebakaran di lahan gambut mengandung polutan berbahaya bagi manusia dan memiliki kadar PM 2.5 yang tinggi. Particulate Matter (PM 2.5) merupakan ukuran penurunan kualitas udara akibat adanya campuran bahan kimia di atmosfer (Kusmartini et al. 2019).

Kebakaran hutan dan lahan di provinsi Riau pada umumnya terjadi di lahan gambut, hal tersebut disebabkan luasan lahan gambut yang besar serta alih fungsi lahan yang tinggi. Tahun 2015 kebakaran hutan dan lahan yang terjadi di Riau telah membakar 186.069 ha lahan dengan 107.000 ha merupakan lahan gambut (Trinirmalaningrum et al. 2016). Kabupaten Bengkalis merupakan salah satu daerah di Provinsi Riau yang

\footnotetext{
${ }^{1}$ Dosen Departemen Silvikultur, Fakultas Kehutanan dan Lingkungan, IPB University

* Penulis korespondensi: e-mail: saharjobambangh@gmail.com

2 Mahasiswa Departemen Silvikultur, Fakultas Kehutanandan Lingkungan, IPB University
}

memiliki luas lahan gambut sebesar 856.386 hektar (Husna 2015).

Pulau Rupat termasuk wilayah administratif kabupaten Bengkalis yang memiliki luasan lahan gambut yang besar. Selain itu, pulau Rupat memiliki riwayat kasus kebakaran hutan dan lahan yang terulang. Tahun 2015 - 2019 kebakaran hutan dan lahan yang terjadi di pulau Rupat sebagian besar terjadi di lahan gambut (KLHK 2019). Umumnya kebakaran yang terjadi di lahan gambut merupakan akibat kurang baiknya tata kelola muka air gambut.

Menurut Peraturan Pemerintah No 57 Tahun 2016 tentang perlindungan dan pengelolaan ekosistem gambut bahwa untuk kriteria maksimum muka air tanah di lahan gambut lebih dari $0,4 \mathrm{~m}$ di bawah permukaan gambut pada titik penataan dan/atau tereksposnya sedimen berpirit dan/atau kwarsa di bawah lapisan gambut. Penelitian ini bertujuan menganalisis faktor penyebab kebakaran hutan dan lahan di pulau Rupat provinsi Riau. Hasil penelitian diharapkan dapat memberikan informasi terkait faktor penyebab kebakaran hutan dan lahan di pulau Rupat provinsi Riau serta rencana pencegahan yang dapat dilakukan kedepannya.

\section{METODE PENELITIAN}

\section{Waktu dan Tempat Penelitian}

Penelitian ini dilaksanakan pada bulan April sampai dengan Mei 2019. Penelitian dilakukan di Laboratorium Kebakaran Hutan dan Lahan Fakultas Kehutanan IPB dan Lembaga Swadaya Masyarakat (LSM) yang bergerak di bidang kehutanan di Pekanbaru, Provinsi Riau.

\section{Alat dan Bahan Penelitian}

Alat yang digunakan pada penelitian ini yaitu alat tulis, perangkat laptop dengan beberapa perangkat lunak 
seperti Microsoft Excel untuk tabulasi serta olah data dan Arc GIS untuk mengetahui kondisi serta status Kawasan, lembar pertanyaan dan kamera.

Bahan yang digunakan dalam penelitian ini berupa data sekunder, diantaranya yaitu:

1. Data curah hujan Tahun 2019 di pulau Rupat, Riau yang diperoleh dari Badan Meteorologi Klimatologi dan Geofisika (BMKG) Riau.

2. Data kondisi lapang kebakaran hutan pulau Rupat tahun 2019 serta status kawasan diperoleh dari Lembaga Swadaya Masyarakat (LSM) Kehutanan Provinsi Riau

3. Data hotspot di pulau Rupat di bulan Januari sampai April 2019 yang diperoleh dari http://modis-catalog.lapan.go.id/monitoring/

4. Data kandungan PM 2.5 selama bulan januari sampai april 2019 yang diperoleh dari https://earth.nullschool.net/

\section{Metode Pengumpulan Data}

Penelitian dilakukan terdiri dari beberapa tahapan, yaitu pengumpulan data, pengolahan data, dan analisis data. Data yang digunakan berupa data kebakaran hutan dan lahan, hotspot, dan curah hujan serta status kawasan yang terbakar di pulau Rupat Provinsi Riau pada periode Januari - April 2019. Data tersebut diperoleh dari Laboratorium Kebakaran Hutan Fakultas Kehutanan IPB. Penelitian dilakukan dengan metode kualitatif mendukung kuantitatif. Pengumpulan data lapang kebakaran hutan di pulau Rupat dari LSM di lakukan dengan diskusi dan wawancara, data tersebut dikomparasikan dengan wawancara yang sifatnya sengaja atau purpossive kepada narasumber terkait kebakaran di pulau Rupat pada periode tersebut.

Proses analisis dilakukan dengan pengamatan hotspot untuk mengetahui koordinat kebakaran yang terjadi. Variabel penduga terjadinya kebakaran berupa keadaan kanal gambut di sekitar area terbakar, kadar PM 2.5 dan curah hujan. Kondisi kanal gambut di area terbakar di dapatkan dari jaringan LSM serta lembaga lainnya yang melakukan pengamatan secara langsung kondisi kanal gambut pasca kebakaran hutan di pulau Rupat tahun 2019. Analisis tersebut berdasarkan kesesuaian pengelolaan kanal gambut dari peraturan pemerintah No 57 Tahun 2016 tentang tentang perlindungan dan pengelolaan ekosistem gambut. Menurut Widyawati (2011), pengelolan kanal gambut yang tidak sesuai akan mengakibatkan kerentanan kebakaran dimusim kemarau dan banjir dimusim hujan.

Variabel PM 2.5 mengetahui keadaan konsentrasi asap pada koordinat hotspot yang ditentukan serta kesesuaian dengan kondisi di lapang. Data hotspot yang digunakan dari Lembaga Penerbangan dan Antariksa Nasional (Lapan) yang diperoleh dari All Satelite selama bulan Januari-April 2019. Kemudian data koordinat enam titik hotspot diolah untuk mengetahui kadar PM 2.5 pada koordinat yang ditentukan selama Januari-April 2019. Data kandungan PM 2.5 yang telah diperoleh, kemudian direkapitulasi dan diolah pada software $M s$. Excel. Data curah hujan satu tahun terakhir didapatkan dari BMKG Provinsi Riau langsung direkapitulasi pada software Ms. Excel.

\section{Kondisi Umum Penelitian}

Pulau Rupat merupakan salah satu pulau yang berada di wilayah Kabupaten Bengkalis Provinsi Riau. Secara geografis pulau Rupat berada pada Koordinat $2^{\circ} 6^{\prime} 35.79^{\prime \prime}$ - 142'29.12"LU dan 101²3'22.91" $101^{\circ} 46^{\prime} 32.87 " B T$. Wilayah pulau Rupat merupakan bagian dari Kabupaten Bengkalis, provinsi Riau.

Pulau Rupat memiliki lahan gambut yang luas sehingga rentan terhadap kebakaran hutan dan lahan jika pengelolaannya kurang lestari. Pada Gambar 1 di tampilkan hotspot selama tahun 2014-2019. Selama kurun waktu tersebut pulau Rupat memiliki 2.575 hotspot dan 1.342 hotspot yang berpotensi menjadi titik api. Selain itu, persebaran titik api selama lima tahun terakhir cenderung mencakup wilayah yang sama. Menurut KLHK (2019), areal yang terbakar di pulau Rupat selama kurun waktu 2015-2019 mencakup kawasan FLEG (Fungsi Lindung Ekologis Gambut), FBEG (Fungsi Budidaya Ekosistem Gambut) dan Kubah Gambut.

\section{HASIL DAN PEMBAHASAN}

Penelitian terkait faktor penyebab kebakaran hutan dan lahan di pulau Rupat dilakukan dengan mengamati enam koordinat hotspot untuk mengetahui kandungan PM 2.5 selama bulan Januari-April 2019. Kesesuaian kondisi hotspot dengan kandungan polutan PM 2.5 menunjukkan kondisi serta dampak kebakaran yang terjadi di pulau Rupat. Variabel penyebab kebakaran hutan dan lahan yang terjadi di pulau Rupat berupa kondisi kanal gambut serta curah hujan. Berdasarkan kondisi kebakaran hutan dan lahan di pulau Rupat memiliki kandungan polutan yang tinggi di bulan tertentu akibat intensitas asap dan hotspot. Selain itu, kanal gambut dan curah hujan mempengaruhi intensitas kebakaran hutan yang terjadi di pulau Rupat.

\section{Kandungan Polutan (PM) 2.5}

Pengamatan kandungan Particullate Matter PM 2.5 pada enam koordinat hotspot yang representatif terhadap
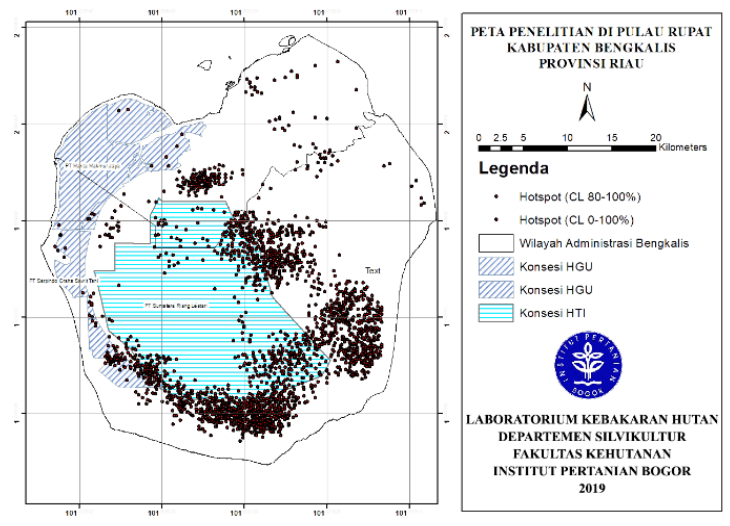

Disiapkan oleh: Fauzan MA (2019)

Gambar 1 Peta penelitian di pulau Rupat Kabupaten Bengkalis Provinsi Riau beserta hotspot dari tahun 2014-2019 Sumber: Jikalahari (2019) disiapkan Fauzan 
kebakaran hutan dan lahan di pulau Rupat tahun 2019 dengan tingkat confidence $100 \%$. Pengamatan dilakukan pada bulan Januari-April 2019 setiap hari pada pukul 00.00 WIB. Kandungan PM 2.5 yang diukur dibandingkan dengan NAB (Nilai Ambang Batas) untuk PM 2.5 sebesar $65 \mu \mathrm{m} / \mathrm{m} 3$ untuk rata-rata 24 jam.

Berdasarkan Gambar 2 diperoleh hasil, bahwa pengukuran kandungan PM 2.5 di bulan Januari memiliki rata-rata nilai PM 2.5 di bawah nilai ambang batas. Nilai PM 2.5 tertinggi di bulan Januari berada pada tanggal 5 Januari. Koordinat 1 dan 2 memiliki nilai di atas ambang batas pada tanggal 5 Januari. Koordinat 1 dan 2 memiliki kandungan PM 2.5 pada tanggal 5 Januari sejumlah nilai $84 \mu \mathrm{g} / \mathrm{m}^{3}$ dan $73 \mu \mathrm{g} / \mathrm{m}^{3}$. Kandungan PM 2.5 yang cenderung di bawah nilai ambang batas disebabkan pada bulan Januari di pulau Rupat memiliki curah hujan yang tinggi. Hal tersebut sesuai bahwa bulan Januari merupakan peralihan antara puncak musim hujan dengan musim kemarau di Riau.

Berdasarkan gambar 3 diperoleh hasil pengukuran kandungan PM 2.5 di bulan februari yang fluktuatif. Hal tersebut diketahui bahwa pada tanggal 1-13 Februari memiliki nilai PM 2.5 dibawah ambang batas. Namun, pada tanggal 14 Februari mengalami peningkatan nilai PM 2.5 dengan puncak nilai PM 2.5 pada tanggal 16 Februari di semua titik koordinat. Koordinat 1 memiliki kandungan PM 2.5 tertinggi di bulan februari sejumlah $2035 \mu \mathrm{g} / \mathrm{m}^{3}$ pada tanggal 16 . Setelah tanggal 16 Februari terjadi penurunan nilai PM 2.5 hingga tanggal 20 Februari dan setelahnya terjadi peningkatan hingga

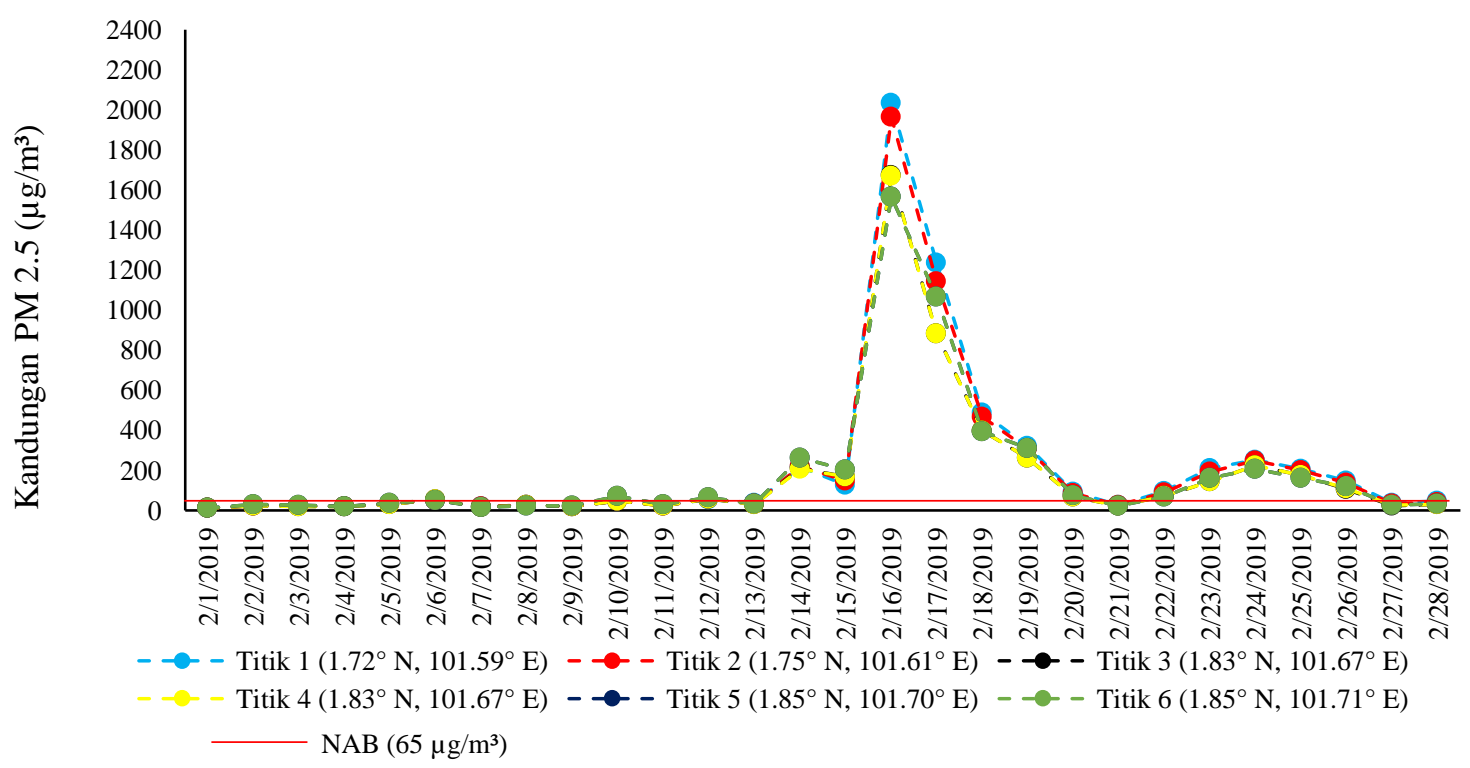

Gambar 2 Kandungan PM 2.5 di enam koordinat hotspot di pulau Rupat pada Januari 2019

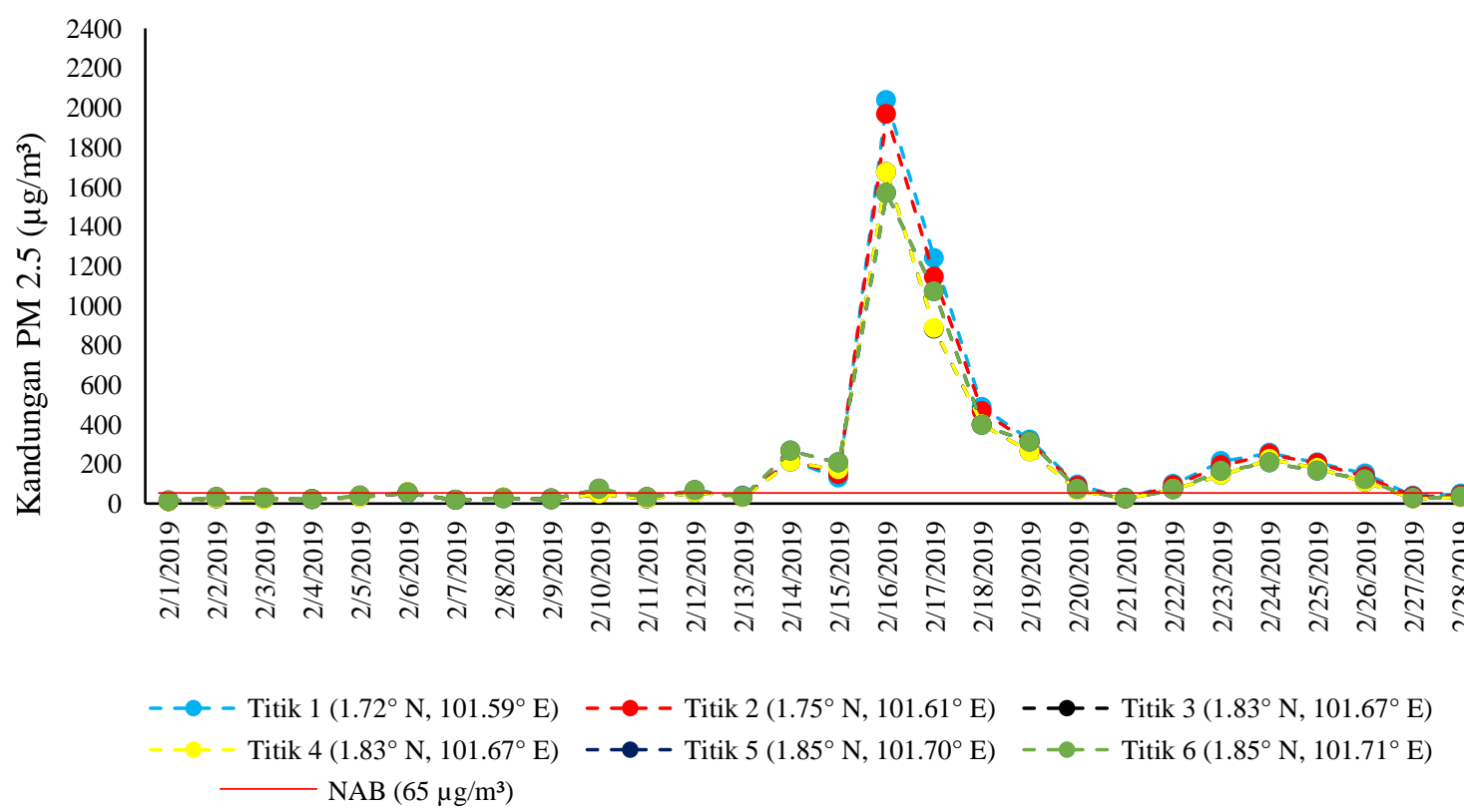

Gambar 3 Kandungan PM 2.5 di enam koordinat hotspot di pulau Rupat pada Februari 2019 
tanggal 25 Februari. Koordinat 4 memiliki kandungan PM 2.5 tertinggi pada tanggal 25 februari dengan nilai $247 \mu \mathrm{g} / \mathrm{m}^{3}$. Peningkatan kandungan PM 2.5 pada bulan februari diketahui lebih tinggi daripada bulan sebelumnya. Hal tersebut dipengaruhi peningkatan hotspot pada bulan februari yang meningkat serta kepekatan asap yang tinggi. Peningkatan kandungan PM 2.5 yang terjadi disebabkan pada bulan Februari hanya memiliki satu hari hujan dengan intensitas $27,0 \mathrm{~mm}$ pada tanggal 5 Februari.

Berdasarkan gambar 4 diperoleh hasil pengukuran PM 2.5 di bulan Maret memiliki nilai yang cenderung fluktuatif serta rata-rata memiliki kandungan PM 2.5 di atas nilai ambang batas. Hal tersebut diketahui bahwa pada tanggal 16-19 Maret terjadi peningkatan nilai PM
2.5 dengan nilai PM 2.5 tertinggi di tanggal 19 Maret. Kandungan PM 2.5 di tanggal 19 tertinggi pada koordinat 1 dengan kandunga polutannya $2319 \mu \mathrm{g} / \mathrm{m}^{3}$. Selain itu nilai terendah pada tanggal 19 pada koordinat 6 dengan kandungan polutan PM 2.5 sejumlah $1083 \mu \mathrm{g} / \mathrm{m}^{3}$. Kemudian, terjadi penurunan setelah tanggal 19 Maret dan kembali terjadi peningkan nilai PM 2.5 pada tanggal 28-29 Maret. Puncak peningkatan tersebut terjadi di tanggal 29 Maret tertinggi pada koordinat 1 dengan kandungan polutan $772 \mu \mathrm{g} / \mathrm{m}^{3}$ dan terendah pada koordinat 6 dengan kandungan polutan $434 \mu \mathrm{g} / \mathrm{m}^{3}$. Penurunan puncak kandungan polutan PM 2.5 pada tanggal 29 Maret disebabkan adanya hujan pada tanggal 29 dan 30 Maret 2019 di Pulau Rupat.

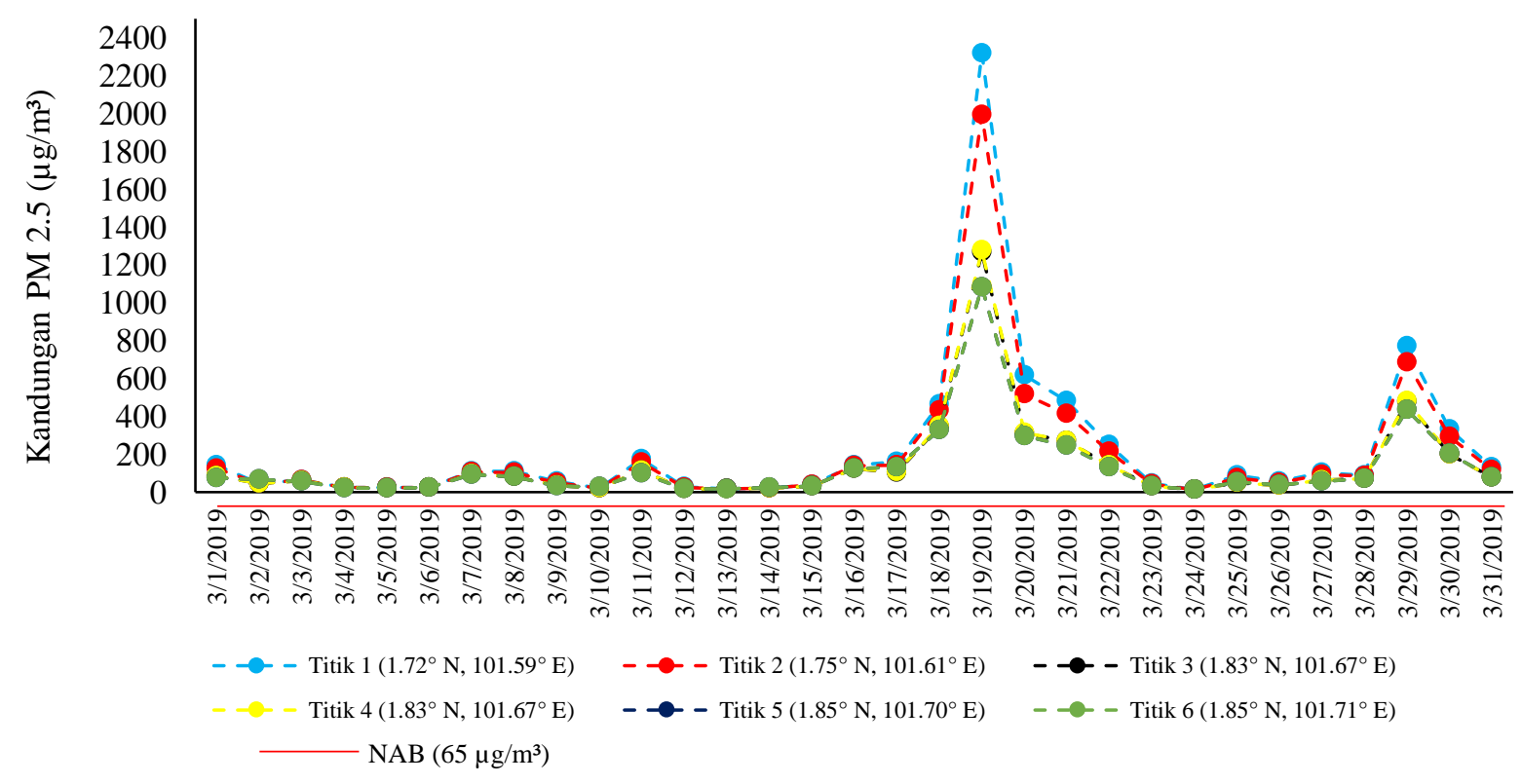

Gambar 4 Kandungan PM 2.5 di enam koordinat hotspot di pulau Rupat pada Maret 2019

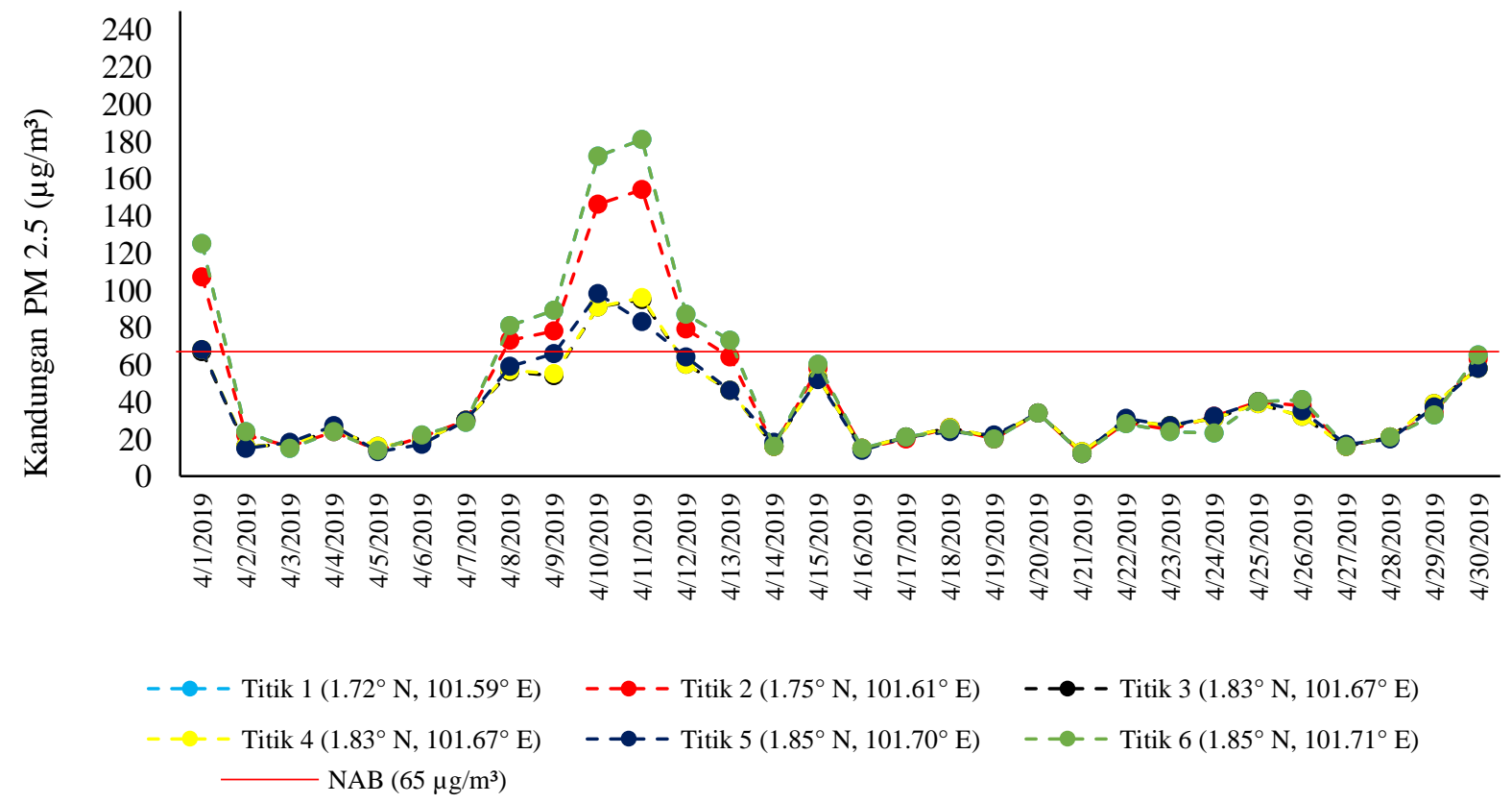

Gambar 5 Kandungan PM 2.5 di enam koordinat hotspot di pulau Rupat pada April 2019 
Berdasarkan gambar 5 diperoleh hasil pengukuran PM 2.5 di bulan April memiliki nilai di atas ambang batas pada tanggal 1 april dan pada tanggal 8-14 April. Pada tanggal 1 April memiliki kandungan polutan PM 2.5 tertinggi pada koordinat 6 dengan kandungan polutan PM 2.5 sejumlah $125 \mu \mathrm{g} / \mathrm{m}^{3}$. Pada tanggal 11 April memiliki kandungan PM 2.5 tertinggi di bulan April. Koordinat 6 memiliki kandungan PM 2.5 tertinggi di tanggal 11 April dengan kandungan polutan sejumlah $181 \mu \mathrm{g} / \mathrm{m}^{3}$.

\section{Kanalisasi Gambut}

Salah satu aktivitas yang paling berpotensi meningkatkan laju degradasi hutan rawa gambut di Indonesia adalah kegiatan pembuatan kanal atau parit (kanalisasi), baik yang dibangun secara legal atau illegal di sekitar hutan lahan gambut. Kanalisasi gambut merupakan salah satu cara untuk menjaga kelestarian gambut serta mengoptimalkan budidaya tanaman di atasnya. Sistem kanal pada gambut disesuaikan dengan kebutuhan tanaman yang akan di tanam sehingga memiliki potensi muka air gambut yang berbeda (Soewandita 2008).

Pulau Rupat merupakan wilayah yang memiliki luasan lahan gambut yang besar. Luas lahan gambut di pulau Rupat seharusnya menjadi benteng alami terhadap kebakaran hutan dan lahan. Hal tersebut terjadi disebabkan gambut merupakan lahan yang bersifat basah sehingga sulit untuk terjadi kebakaran hutan dan lahan. Hutan rawa gambut yang belum terdrainase menyimpan air secara efektif di gambut sepanjang tahun dan dapat mempertahankan tingkat permukaan air (water table) yang tinggi, sehingga kawasan tersebut biasanya menjadi sulit terbakar (Widyawati 2011).

\section{Curah Hujan}

Curah hujan terjadi karena adanya perpindahan massa air basah ke tempat yang lebih tinggi sebagai respon adanya perbedaan tekanan udara antara dua tempat yang berbeda ketinggiannya. Hasil data curah hujan di pulau Rupat, provinsi Riau, disajikan pada Tabel 1 .

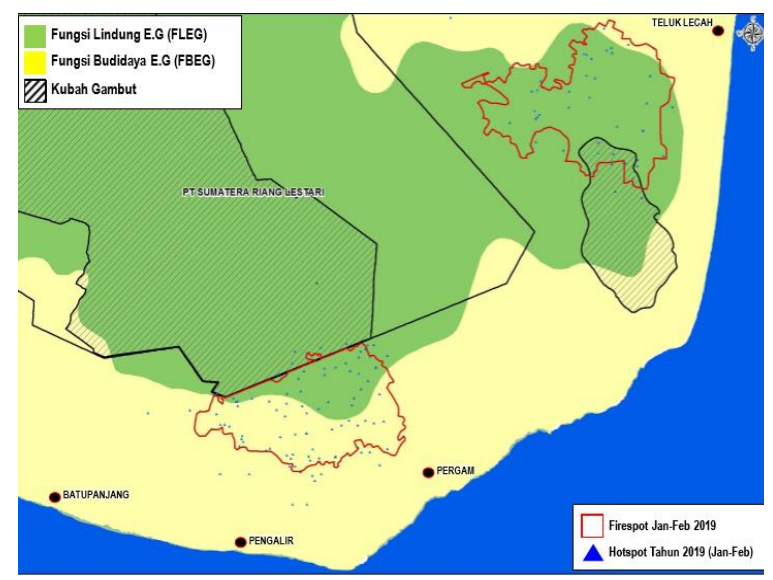

Gambar 6. Peta sebaran titik api 2019 beserta kawasan gambut di pulau Rupat kabupaten Bengkalis provinsi Riau (Sumber: KLHK 2019)
Tabel 1 menunjukkan curah hujan di pulau Rupat, provinsi Riau pada bulan Februari 2018 hingga bulan April 2019. pada periode tersebut mencapai nilai minimum pada bulan Februari 2019 dengan nilai $27 \mathrm{~mm}$ dengan hari hujan sebanyak 1 kali. sedangkan bulan Oktober 2018 memiliki nilai curah hujan maksimum dengan nilai $531 \mathrm{~mm}$ dengan hari hujan sebanyak 15 kali.

\section{Pembahasan}

Kebakaran hutan dan lahan di pulau Rupat pada tahun 2019 mengakibatkan rusaknya lahan gambut serta kandungan polutan yang berbahaya. Kebakaran hutan dan lahan tersebut dipegaruhi kondisi gambut dan curah hujan serta berdampak kepada peningkatan polutan PM 2.5. Particullate Matter (PM) merupakan polutan utama pemberi dampak pada kesehatan yang merupakan fasa campuran antara beberapa senyawa kimia berbentuk partikel. Berdasarkan ukurannya PM di kelompokkan menjadi dua yaitu PM 2.5 dan PM 10. Penentuan tersebut didasari ukuran diameter partikel didalamnya Ukuran diameter PM 10 adalah 2,5-10 $\mu$ m sedangkan PM 2.5 adalah $<2,5 \mu \mathrm{m}$ (Faisal dan Susanto 2017). Kebakaran hutan khususnya lahan gambut memberikan dampak peningkatan kadar PM 2.5.

Partikel PM 2.5 bersifat karsinogenik dan salah satu penyebab penyakit Infeksi Saluran Pernafasan Akut (ISPA). Berdasarkan sifatnya yang mempengaruhi kesehatan, kandungan PM 2.5 memiliki batas ambang sesuai Peraturan Pemerintah RI No. 41 Tahun 1999 tentang Pengendalian Pencemaran Udara yaitu baku mutu udara ambien nasional untuk PM 2,5 sebesar 65 $\mu \mathrm{m} / \mathrm{m} 3$ untuk rata-rata 24 jam.

Perubahan kandungan PM 2.5 di tiap bulan disebabkan oleh perbedaan emisi yang terjadi. Perbedaan tersebut di pulau Rupat terjadi akibat adanya akumulasi

Tabel 1 Data curah hujan di pulau Rupat, provinsi Riau

\begin{tabular}{lcc}
\hline \multicolumn{1}{c}{ Bulan } & $\begin{array}{c}\text { Curah Hujan } \\
(\mathrm{mm})\end{array}$ & Hari Hujan \\
\hline Februari 2018 & 106 & 4 \\
Maret 2018 & 384,5 & 12 \\
April 2018 & 417 & 11 \\
Mei 2018 & 383 & 8 \\
Juni 2018 & 291 & 7 \\
Juli 2018 & 96 & 4 \\
Agustus 2018 & 108 & 6 \\
September 2018 & 130 & 10 \\
Oktober 2018 & 531 & 15 \\
November 2018 & 250,5 & 7 \\
Desember 2018 & 224 & 10 \\
Januari 2019 & 52,5 & 5 \\
Februari 2019 & 27 & 1 \\
Maret 2019 & 37,4 & 7 \\
April 2019 & 380 & 7
\end{tabular}

Sumber: Badan Meteorologi Klimatologi dan Geofisika Sultan Syarif Kasim II, Riau (2019) 
hotspot yang berbeda serta dipegaruhi oleh cuaca dan intensitas kebakaran. Menurut Barus et al. (2019), faktor meteorologi dan jenis bahan yang terbakar mempengaruhi kandungan PM 2.5. Pengukuran nilai PM 2.5 dilakukan pada bulan Januari-April 2019 yang disajikan memiliki nilai kandungan PM 2.5 tertinggi di bulan Maret. Hal tersebut dikorelasikan dengan intensitas curah hujan bahwa selama Januari-Maret provinsi Riau mengalami musim kemarau. Curah hujan dapat membersihkan polusi di atmosfer dan melarutkan polutan gas. Curah hujan berkorelasi negatif terhadap polutan di udara (Agustin, 2012).

Peningkatan PM 2.5 dalam kebakaran hutan dipengaruhi juga oleh bahan bakar yang terbakar. Selain itu, kandungan PM 2.5 pada Januari-April 2019 memiliki nilai kandungan di atas ambang batas normal yang tidak berbeda pada enam titik koordinat di bulan yang sama. Hal tersebut diketahui bahwa kandungan PM 2.5 di suatu koordinat dipengaruhi oleh arah angin serta kecepatan angin pada suatu daerah (Sastrawijaya 2009). Semakin tinggi kecepatan angin akan berpengaruh terhadap perpindahan partikel asap.

Menurut Rahutomo dan Sutarta (2001), beberapa permasalahan yang terjadi dalam pembukaan lahan gambut sebagai lahan perkebunan dapat diatasi dengan beberapa upaya antara lain pengaturan drainase dan tata air, pencegahan luapan air pasang dan oksidasi parit, pencucian sulfat masam akibat oksidasi pirit, serta pengapuran untuk meningkatkan nilai $\mathrm{pH}$ tanah. Pembukaan saluran drainase bertujuan untuk mengatur permukaan air tanah dan tergantung pada jenis gambut yang akan diusahakan. Sistem pembuatan kanal yang tidak tepat menyebabkan terganggunya sistem hidrologi kawasan hutan dan lahan gambut.

Berdasarkan gambar 6 diketahui areal terbakar di pulau Rupat terdapat di Fungsi Lindung Ekosistem Gambut (FLEG), Fungsi Budidaya Ekosistem Gambut (FBEG) dan Kubah gambut. Menurut Peraturan Menteri Lingkungan Hidup Dan Kehutanan Republik Indonesia Nomor P.14 Tahun 2017 tentang Tata Cara Inventarisasi Dan Penetapan Fungsi Ekosistem Gambut tentang FLEG, FBEG dan kubah Gambut. Bahwa FLEG dan kubah gambut memiliki fungsi lindung untuk ekosistem gambut serta berfungsi sebagai reservoir air gambut di bawahnya.

Menurut Badan Restorasi Gambut (BRG 2018), bahwa pulau Rupat merupakan prioritas restorasi gambut. Meski demikian kebakaran hutan tetap terjadi di lokasi prioritas restorasi gambut tersebut. Penyebab terjadinya kebakaran di prioritas retorasi gambut disebabkan oleh kurang terealisasinya pelaksanaan rencana pembasahan kembali dan pembuatan sekat kanal meskipun sudah dilakukan pemetaan terhadap lokasi yang akan dibangun. Selain itu wilayah prioritas restorasi termasuk wilayah konsesi. Hal tersebut sesuai dengan penelitian Pantau Gambut (2019), tentang kebakaran hutan dan lahan di pulau Rupat di kelurahan Pergam bahwa hampir semua titik panas berada dan atau berdekatan dengan rencana pembangunan sekat kanal ataupun sumur bor. Jika implementasi rencana restorasi tepat waktu, maka seharusnya dapat mengurangi dan mempermudah upaya pemadaman saat kebakaran hutan dan lahan.
Kebakaran hutan di pulau Rupat terjadi di sekitar wilayah HTI dan Hutan Produksi Konversi (HPK) yang kurang produktif (KLHK 2019). Menurut Hafni (2015), kondisi tersebut menyebabkan jumlah titik panas yang tertangkap satelit relatif tinggi pada lahan tidak produktif. Lahan yang terbakar di pulau Rupat mayoritas belum dimanfaatkan sehingga perlunya pengelolaan dengan reforma agraria atau perhutanan sosial sebagai bentuk pencegahan kebakaran hutan.

Penanganan pencegahan serta penanggulangan kebakaran yang terjadi di area konsesi merupakan tanggung jawab badan usaha. Hal tersebut sesuai dengan Peraturan Pemerintah No 57 Tahun 2016 tentang Perlindungan dan Pengelolaan Ekosistem Gambut bahwa pemulihan ekosistem gambut dibebankan kepada Penanggung jawab usaha dan/atau kegiatan, untuk areal usaha dan/atau kegiatan. Selain itu, peta persebaran infrastruktur sekat kanal dan sumur bor banyak berada di area konsesi sehingga perlunya koordinasi untuk wewenang supervisi dari pemberi izin yang kemungkinan besar adalah KLHK (KLHK, 2019). Hal tersebut sesuai pada gambar 6 bahwa wilayah konsesi mencakup kubah gambut yang memerlukan perhatian khusus untuk restorasi. Sehingga kedepan perlunya perhatian serius dari semua pihak untuk melakukan perbaikan gambut serta pencegahan kebakaran hutan di pulau Rupat.

Menurut Siswanto (1993) dalam Hadiprasetya (2009), iklim tropis yang dimiliki Indonesia secara umum menimbulkan dua musim, yaitu musim penghujan dan musim kemarau. Situasi tertentu sering terjadi suasana kekeringan yang sangat tajam dengan curah hujan rendahnya. Situasi iklim di atas akan mempunyai pengaruh terhadap terjadinya kebakaran hutan melalui pengeringan bahan bakar yang berupa serasah dan limbah kayu hasil pembakaran hutan, baik yang berada di dalam maupun di luar hutan serta penambahan jumlah bahan bakar yang berupa serasah hutan dan gambut kering.

Peningkatan intensitas kebakaran terjadi ketika curah hujan mencapai nilai minimum dan kebakaran tetap terjadi bahkan semakin membesar pada saat curah hujan mulai meningkat. Hal tersebut terlihat dari tabel 1 bahwa tingkat kandungan PM 2.5 tertinggi di bulan Maret meskipun curah hujan bulan Maret lebih tinggi dari bulan Februari. Hal tersebut diketahui bahwa gambut memiliki sifat kering tidak kembali (irreversible drying) sehingga curah hujan sedikit berpengaruh terhadap kadar air lahan gambut yang telah kering tidak kembali dan terjadi kebakaran di bawah permukaan. Hal tersebut diketahui bahwa faktor cuaca mempengaruhi kadar air bahan bakar mati dan kemudahan bahan bakar serta berpengaruh terhadap penyulutan dan penyebaran kebakaran (Chandler et al. 1983).

Curah hujan di tahun 2018 pada bulan Februari sampai April lebih besar dari curah hujan bulan Februari sampai April tahun 2019. Hal tersebut dipengaruhi oleh iklim global yang terjadi. Menurut BMKG (2019), berdasarkan analisis ENSO bahwa akan terjadi El Nino lemah pada tahun 2019 akibat aliran massa uap air dari Indonesia ke Samudra Hindia. Menurut Siwi (2013), curah hujan memiliki korelasi terhadap peningkatan 
intensitas kebakaran hutan. Provinsi Riau memiliki sejarah kebakaran hutan selama dua kali dalam setahun.

Menurut Aldrian dan Susanto (2003), daerah Bengkalis yang memiliki dua puncak curah hujan (Oktober-Desember dan Maret-Mei) termasuk dalam Region B (tipe ekuatorial). Terjadinya kebakaran hutan dan lahan di pulau Rupat, provinsi Riau di Tahun 2019 terjadi pada musim kemarau. Hal tersebut terjadi karena proses yang dilakukan manusia dengan memanfaatkan faktor cuaca untuk mempermudah proses pembakaran ( Nurkholis et al. 2016).

\section{SIMPULAN DAN SARAN}

\section{Simpulan}

Kebakaran hutan dan lahan yang terjadi di pulau Rupat pada tahun 2019 termasuk ke dalam wilayah prioritas restorasi gambut, dimana kebakaran hutan dan lahan terjadi juga pada tahun 2015. Kebakaran hutan dan lahan tersebut terjadi di area yang kurang produktif dan mengakibatkan asap dengan kandungan polutan PM 2.5 yang tinggi di bulan Februari-Maret 2019. Pengelolaan kanal yang kurang baik, kondisi gambut yang rusak serta cuaca yang memasuki El Nino lemah menjadi penyebab luasnya kebakaran hutan dan lahan di pualu Rupat tahun 2019.

\section{Saran}

Penelitian terkait faktor penyebab kebakaran hutan dan lahan di pulau Rupat, Riau dilakukan dengan analisa bersama jaringan lembaga swadaya masyarakat bidang kehutanan yang melakukan penjajakan lapangan. Harapannya perlu penelitian dan analisa secara aktual kondisi restorasi gambut di pulau Rupat serta penelitian tentang pencegahan kebakaran hutan dan lahan berbasis masyarakat di pulau Rupat.

\section{DAFTAR PUSTAKA}

[BMKG] Badan Meteorologi Klimatologi dan Geofisika (ID). 2019. Perkembangan Cuaca Terkini (Weather Update). [diunduh pada 2019 nov 21]. Tersedia pada: http://jakberketahanan.org/wpcontent/uploads/2019/01/Wather-UpdateBMKG.pdf.

[BRG] Badan Restorasi Gambut (ID). 2018. Rencana Kerja Restorasi Gambut Tahun 2018; 2018 Jan 3; Jakarta, Indonesia. [diunduh pada 2019 nov 21]. Tersedia pada: https://brg.go.id/wpcontent/uploads/2019/04/RENJA-2018-SAH.pdf.

[KLHK] Kementerian Lingkungan Hidup dan Kehutanan (ID). 2019. Rencana Pengelolaan Hutan dan Pengendalian Karhutla Pulau Rupat, Kab. Bengkalis, Prov. Riau; 2019 mar 11; Jakarta, Indonesia.

Agustin S. 2012. Hubungan Particullate Matter (PM10) dan Nitrogen Dioksida $\left(\mathrm{NO}^{2}\right)$ Dengan Jumlah Asma Di Jakarta Pusat Tahun 2007-2011
[Skripsi]. Depok (ID): Fakultas Kesehatan Masyarakat Universitas Indonesia.

Aldrian E, Susanto RD. 2003. Identification of three dominant precipitation regions within Indonesia and their relationship to sea surface temperature. Int. J. Climatol. 23: 1435-1452.

Barus RAB, Chandra I, Fathona IW. 2019. Rancangan Bangun Portable Weather Station Dalam Mendukung Pengamatan Mikropartikel Di Cekungan Udara Bandung Raya. e-Proceeeding of Engineering. 6(1): 1291-1297.

Chandler, C.P. Cheney, L. Trabaud and D. Williams. 1983a. Fire in Forestry Vol. I Forest Fire Behaviour and Effects. John Wiley and Sons, Inc. Canada.

Eyes on the Forest. 2019. Laporan Investigatif Eyes on the Forest: Kebakaran gambut masih menghantui, restorasi gambut sudah sejauh mana? Pemerintah tampaknya ingin balik ke masa sebelum 2015 dan tidak tegas dalam restorasi gambut di konsesi HTI. [diunduh 2019 nov 21]. Tersedia pada: http://eyesontheforest.or.id/uploads/default/report /Laporan_EoF_(Agu2019)_Kebakaran_gambut_ masih_menghantui_restorasi_sejauh_mana.pdf.

Faisal HD dan Susanto AD. 2017. Peran masker/respirator dalam pencegahan dampak kesehatan paru akibat polusi udara. Jurnal Respirasi 3(1): 18-25.

Hadiprasetya Y. 2009. Identifikasi Penyebab Kebakaran Hutan dan Upaya Penanggulangannya di Taman Nasional Gunung Ciremai, Jawa Barat. [skripsi]. Bogor (ID): Fakultas Kehutanan IPB.

Hafni DAF. 2015. Variabilitas Iklim Dan Kejadian Kebakaran Hutan Dan Lahan Gambut Di Kabupaten Bengkalis, Provinsi Riau [skripsi]. Bogor (ID): Fakultas Kehutanan Institut Pertanian Bogor.

Husna HA. 2015. Kerjasama Universitas Riau dan Universitas Kyoto dalam Pengelolaan Ekosistem Gambut di Kabupaten Bengkalis Tahun 20102014. Jom fisip. 2(2): 1-11.

Kusmartini I, Adventini N, Sari DK, Kurniawati S, Lestiani DD, Santoso M. 2019. Karakterisasi unsur pm 2,5 pada periode kebakaran hutan di Pekanbaru dengan teknik analisis aktivasi neutron. Jurnal Sains dan Teknologi Nuklir Indonesia. 20(1): 29-44.

Nurkholis A, Suci AW, Abdillah A, Widiastuti AS, Rahma AD, Maretya DA, Wangge GA, Widyaningsih Y. 2016. Analisis Temporal Kebakaran Hutan dan Lahan di Indonesia Tahun 1997 dan 2015 (Studi Kasus Provinsi Riau). Kebakaran Hutan dan Lahan. Hlm: 1-15.

Pantau Gambut. 2019. Analisa lapangan di wilayah terintervensi restorasi di Riau. Jakarta (ID): Pantau Gambut. Hlm 15-18. [diunduh 2019 nov 21]. Tersedia pada:https://pantaugambut.id/uploads/default/arti cles/document/PGLaporan_Kebakaran_Gambut_ di_Wilayah_Terintervensi_Restorasi_di_Riau.pdf

Peraturan Menteri Kehutanan Republik Indonesia Nomor: $\quad$ P.12/Menhut-Ii/2009 Tentang 
Pengendalian Kebakaran Hutan. Jakarta (ID): Kemenkumham. Hlm 4.

Peraturan Menteri Lingkungan Hidup Dan Kehutanan Republik Indonesia Nomor: P.14/Menlhk/Setjen/Kum.1/2/2017 Tentang Tata Cara Inventarisasi Dan Penetapan Fungsi Ekosistem. Jakarta (ID): Kemenkumham.

Peraturan Pemerintah Republik Indonesia Nomor 41 Tahun 1999 tentang pengendalian pencemaran udara. Jakarta (ID): Kemenkumham. Hlm 27

Peraturan Pemerintah Republik Indonesia no 57 tahun 2016 tentang perubahan atas peraturan pemerintah nomor 71 tahun 2014 tentang perlindungan dan pengelolaan ekosistem gambut. Jakarta (ID): Kemenkumham.

Rahutomo. S, Sutarta ES. 2001. Kendala budidaya kelapa sawit pada lahan tanah sulfat masam. Warta ppks. 9(1):9-15.

Sastrawijaya AT. 2009. Pencemaran Lingkungan. Jakarta (ID): Rineka Cipta.
Siwi R. 2013. Perbandingan Sumber Hotspot Sebagai Indikator Kebakaran Hutan Dan Lahan Gambut Dan Korelasinya Dengan Curah Hujan Di Desa Sepahat, Kabupaten Bengkalis, Provinsi Riau [skripsi]. Bogor (ID): Fakultas Kehutanan Institut Pertanian Bogor.

Soewandita H. 2008. Studi muka air tanah gambut dan implikasinya terhadap degradasi lahan beberapa kubah gambut di kabupaten siak. JAI. 4(2): 103108.

Syaufina L. 2008. Kebakaran Hutan dan Lahan di Indonesia. Malang (ID): Bayumedia.

Trinirmalaningrum, Dalidjo N, Siahaan FR, Widyanto U, Achsan IU, Primandani T, Wardana KW. 2016. Di Balik Tragedi Asap: Catatan Kebakaran Hutan dan Lahan 2015. Jakarta (ID): Asia Foundation.

Widyawati E. 2011. Kajian optimasi pengelolaan lahan gambut dan isu perubahan iklim. Jurnal tekno hutan tanaman. 4(2):57-68. 